\title{
Qualitative Performance of Different Soil and Water Conservation Measures at Shevadi-Yenoli Watershed
}

\author{
S. C. Mundhe*, S. D. Payal and J. P. Shewale \\ Department of Soil and Water Conservation Engineering, College of Agricultural Engineering \\ and Technology, VNMKV Parbhani Maharashtra, India \\ *Corresponding author
}

\section{A B S T R A C T}

\section{Keywords}

Silt deposited,

Earthen

embankment,

Shevadi-yenoli,

Continuous contour trenches

Article Info

\section{Accepted:}

15 January 2021

Available Online:

10 February 2021
The research study on, 'Impact evaluation of Shevadi-Yenoli watershed development in Parbhani dist. of Maharashtra' was carried out during the year 2019-20 at Shevadi village Jintur taluka. The Shevadi-Yenoli watershed development programme was implemented by Agriculture Department of Maharashtra Government of Jintur Tahasil, dist. Parbhani under integrated watershed management programme, funded by NHM/EGS. Shevadi-Yenoli watershed (1772.76 ha) was developed by Department of Agriculture, Government of Maharashtra. Different soil and water conservation structures i.e., continuous contour trenches, loose boulder structures, earthen embankment were undertaken in the watershed. The present dimension of the structures i.e., top width, bottom width and depth were measured with the help of measuring tape and compared with designed dimensions. Data of designed dimensions of structures were collected from office of TAO, department of agriculture, Jintur, dist. Parbhani. The area of silt deposited was measured. Volume of silt deposited was determined by multiplying the silt deposited area and depth of silt deposited. Weight of silt deposited was calculated by multiplying the volume of deposited silt to the bulk density of silt. The bulk density of silt was considered for calculation purpose as 1.30 $\mathrm{gm} / \mathrm{cc}$. Based on the results obtained next conclusions were drawn it was found that the cross-sectional area of CCT, EE, LBS, reduced by 29.35-35.00, 12.94-19.23, 13.69-20.96 percent. The storage capacity of CCT, EE, LBS was reduced by 32.34 , $16.20,16.18$ percent due to the deposition of silt over the period of four years after construction.

\section{Introduction}

Agriculture is the mainstay of Indian economy and depends to a large extent on natural resources such as soil, water and vegetation.
These resources are limited in supply and are limited in supply and are being consumed every day. Agricultural productivity depends on the conservation and management efficiency of these resources. Soil and water 
conservation are very important in Indian agriculture. A watershed is the geographical area through which water flows through land and drains into common body of water, be it a stream, river, lake or ocean. Soil and water are essential resources for human survival. Various agricultural activities are related to land, and the prosperity of a country depends on the quality of its land resources. One of the main reasons for the low productivity is that agriculture is the deterioration of soil due to erosion.

The main factors of soil erosion in India are excessive deforestation, excessive grazing and wrong agricultural practices. The geographical area of Indian is $328.73 \mathrm{M}$ ha, out of which net cultivated area is $142.22 \mathrm{M}$ ha. Out of total geographical area of India, about $175 \mathrm{M}$ ha suffer varying degrees of soil degradation in that they are either under erosion, water logging, shifting cultivation or salinity. About 5334 million tones $(16.4 \mathrm{t} / \mathrm{ha})$ of top soil are estimated to be lost every year (Dhruva Narayana, 1993). The Gross Cropped Area in Maharashtra is 225.56 lakh ha and the Net Cropped Area is 174.73 lakh ha. Cultivable waste, current fallow and other fallow land is $11 \%$ of the geographical area of the State. Gross Irrigated area is 44.19 lakh ha and $80 \%$ of the area is rain fed. Small and marginal farmers holdings are 90 lakh which is $70 \%$ of the total holdings. The state has a large area under alkaline soil and saline soil which is 4.23 lakh ha and 1.84 lakh ha respectively.

More than $50 \%$ soil is deficient in zinc. Deficiency of iron and manganese is also apparent in many districts. (RKVY, 2007).India faces the water shortage, not only due to erratic and uncertain rainfall in terms of time and space but to faulty land water and water management practices. Water availability is low because of huge loss through runoff due to lack of soil and water conservation measures.

\section{Materials and Methods}

\section{Description of Shevadi-Yenoli watershed}

Shevadi-yenoli watershed was a part of Purna sub-basin, which drains in Godavari river. The micro watershed GP-55 was implemented during the year 2014-15 in shevadi village of Jintur tahasil of Parbhani district, under the project of IWMP2014-15 (GP-55).

\section{Location of study}

Shevadi-Yenoli watershed falls under Jinturtahsil of Parbhani district of Marathwada region falls under assured rainfall zone. Shevadi-Yenoli watershed located $3 \mathrm{~km}$ away from the Jintur tahsil in Parbhani district. The watershed development programme was initiated during the year 2014-15.Parbhani is situated in between $19^{\circ} 62^{\prime}$ North latitude and $76^{\circ} 70^{\prime}$ East longitude and at $455 \mathrm{~m}$ from mean sea level. (Department of Agriculture, Jintur)

\section{Soil and topography}

The total geographical area of the ShevadiYenoli watershed is 1772.76 ha. Topography was undulating with semi-arid area. The total cultivable land in watershed is 1652.76 ha. Soils were medium to deep black and mostly clay in texture with bulk density $1.30 \mathrm{gm} / \mathrm{cc}$ and $\mathrm{pH} 7.5$. Population of shevadi village was 2567 of which 1287 were males while 1280 were females as per population census 2011 .

\section{Climate}

The average rainfall of the region is around 900-950 $\mathrm{mm}$ with average number of rainy days 48. South-west monsoon was the major source of rainfall for the region. The region falls under semi-arid tropics having highest temperature of $43^{\circ} \mathrm{C}$ during the month May. While the lowest temperature of $11^{\circ} \mathrm{C}$ during 
December. The rainfall was uneven erratic and varies from year to year. About 90 per cent of the rainfall was being received during the month of June to September.

\section{Measurement of dimensions of structures}

In present study, different soil and water conservation structures like continuous contour trenches, earthen embankment, loose boulder structures, were evaluated. The existing dimension of the structures i.e., top width, bottom width and depth were measured with the help of measuring tape and compared with the designed dimensions for determining the percent change in dimensions of different structures. Data of designed dimensions of each structure was collected from Office of TAO, Department of Agriculture, Jintur, dist. Parbhani.

\section{Measurement of silt deposition}

The observations on silt deposition of different structures i.e. depth of silt deposited, area of silt deposited were recorded. For this, small pits were excavated in impounding area of the structure up to a depth of original ground surface at different location and average depth of silt deposited was determined. The area of silt deposited was measured. Volume of silt deposited at each structure was determined by multiplying the silt deposited area and depth of silt deposited. Weight of silt deposited was calculated by multiplying the volume of deposited silt to the bulk density of silt. The bulk density of silt was considered for calculation purpose was $1.30 \mathrm{gm} / \mathrm{cc}$.

\section{Results and Discussion}

\section{Impact evaluation of continuous contour trenches}

In Shevadi-Yenoli watershed continuous contour trenching work was undertaken in 105 ha area at upper ridge of catchment area having slope range between $4-12 \%$ to control runoff and soil erosion. Continuous contour trenching involves a construction of small trench with about $1 \times 1 \mathrm{~m}$ along the contour line on non-cultivable land (Table 1).

\section{Changes in dimensions of continuous contour trenches}

The present dimension of the continuous contour trenches was calculated by measuring top width, bottom width and depth with the help of measuring tape and compared with designed dimensions.

Data presented in Table 2 indicated that for all selected CCTs top width were increased, while bottom width reduced and depth was reduced during the period of four years after construction. Increase in top width of CCTs might be due to inflow of water from upstream side while reduction in depth was due to the deposition of silt per cent reduction in cross sectional area of CCTs was in the range between 29.35 to 35.00 per cent. On an average 32.34 per cent reduction in cross sectional area of CCTS was noticed as compared to design cross sectional area of continuous contour trenches.

\section{Silt deposited in continuous contour trenches}

The observations on silt deposition were calculated by depth of silt deposited in $\mathrm{CCT}^{\text {ee }} \mathrm{S}$ area. It is measured by excavating small pit to the original ground surface \& area of silt deposited was measured. Volume of silt deposited is calculated by multiplying depth and area of silt deposited. Weight of silt deposited is calculated by multiplying volume of silt deposited to bulk density of silt.

From table 3, it was indicated that average depth of silt deposited and area of silt 
deposited in continuous contour trenches ranged between 0.12 to $0.20 \mathrm{~m}$ and 78.75 to $105 \mathrm{~m} 2$ respectively while weight of silt deposited in different CCTs ranged from 10.89 to 21.00 tonnes. Total 78.64 tonnes silt was deposited in selected continuous contour trenches over the period of four years after their construction. From the results obtained, it was found that earthen embankments were helped in arresting the soil on their upstream side and thereby helped in reducing the soil erosion. From these results, it was found that CCTs were helped in arresting the soil and thereby in reducing the soil erosion. The deposition of silt and conservation of the moisture in CCTs created a favorable condition to stand good grass as well as vegetative cover on the bunds formed on downstream side of CCT. Plate No. 1- shows the measuring the present dimensions of continuous contour trenches

\section{Impact evaluation of earthen embankments}

In shevadi-yenoli watershed development total twelve number of earthen embankments were constructed out of which four earthen embankments were selected for the present study. An earthen embankment was araised confining structures made from compressed soil. They were mostly built with clay, sand and gravel hence called as earth fill dams. This was also used for increasing infiltration detention and retention of water to enable deep percolation.

\section{Changes in dimensions of earthen embankments}

The present dimension of the earthen embankments was calculated by measuring top width, bottom width and depth with the help of measuring tape and compared with designed dimensions. From table 4 , it was indicated that present top width was increased as compared to design top width while design height of earthen embankments was reduced as compared to present height. No change was observed in the design as well as present bottom width of the earthen embankments. Increase in top width and reduction in height of embankment was observed due to compaction of earthen embankments. Data presented in revealed that per cent reduction in cross sectional area of selected earthen embankments ranged between 12.94 to 19.23 per cent with an average value 16.20 over the period of four years.

\section{Silt deposited in earthen embankments}

The observations on silt deposition are calculated by depth of silt deposited in EE's depth. It was measured by excavating small pit to the original ground surface $\&$ area of silt deposited was measured. Volume of silt deposited is calculated by multiplying depth and area of silt deposited. Weight of silt deposited was calculated by multiplying volume of silt deposited to bulk density of silt.

From Table 5, it was clear that average depth of silt deposited and weight of silt deposited in selected earthen embankments ranged between 0.16 to $0.22 \mathrm{~m}$ and 8.32 to 22.30 tonnes respectively. The weight of silt deposited at all four earthen embankments was worked out as 53.38 tonnes over the period of four year after their construction. From the results obtained, it was found that earthen embankments were helped in arresting the soil on their upstream side and thereby helped in reducing the soil erosion. Plate No. 2 - Measuring silt deposited in earthen embankment structures located at Shevadi- Yenoli watershed 2019-20.

\section{Impact evaluation of loose boulder structures}

The loose boulder structures were constructed along the drainage line to reduce the velocity of water also to prevent channel erosion. 
Table.1 Soil and water conservation structures located in shevadi-yenoli watershed

\begin{tabular}{|c|c|c|}
\hline Sr. No. & Name of Structures & $\begin{array}{c}\text { No. of structures constructed in watershed } \\
\text { area }\end{array}$ \\
\hline $\mathbf{1}$ & Continuous contour trenches & 105 ha \\
\hline $\mathbf{2}$ & Earthen embankment & 4 \\
\hline $\mathbf{3}$ & Loose boulder structures & 4 \\
\hline
\end{tabular}

Table.2 Design and present dimensions of continuous contour trenches

\begin{tabular}{|c|c|c|c|c|c|c|c|c|c|}
\hline \multirow{2}{*}{$\begin{array}{l}\text { CCT } \\
\text { Line } \\
\text { NO }\end{array}$} & \multicolumn{4}{|c|}{ Design Dimensions } & \multicolumn{4}{|c|}{ Present Dimensions } & \multirow{2}{*}{$\begin{array}{c}\text { Percent } \\
\text { reduction in } \\
\text { C/S area } \\
\left(\mathbf{m}^{\mathbf{2}}\right)\end{array}$} \\
\hline & $\begin{array}{l}\text { TW } \\
\text { (m) }\end{array}$ & $\begin{array}{l}\text { BW } \\
\text { (m) }\end{array}$ & $\begin{array}{c}\text { D } \\
(\mathrm{m})\end{array}$ & $\begin{array}{c}\text { C/S } \\
\text { area } \\
\left(\mathrm{m}^{2}\right)\end{array}$ & $\begin{array}{l}\text { TW } \\
\text { (m) }\end{array}$ & $\begin{array}{l}\text { BW } \\
(\mathbf{m})\end{array}$ & $\begin{array}{c}\text { D } \\
(\mathrm{m})\end{array}$ & $\begin{array}{c}\text { C/S area } \\
\left(\mathbf{m}^{2}\right)\end{array}$ & \\
\hline 1. & 0.60 & 0.55 & 0.35 & 0.201 & 0.64 & 0.50 & 0.25 & 0.142 & 29.35 \\
\hline 2. & 0.60 & 0.60 & 0.30 & 0.180 & 0.62 & 0.55 & 0.20 & 0.117 & 35.00 \\
\hline 3. & 0.65 & 0.55 & 0.32 & 0.192 & 0.68 & 0.45 & 0.23 & 0.129 & 32.81 \\
\hline \multirow[t]{2}{*}{4.} & 0.65 & 0.55 & 0.30 & 0.180 & 0.67 & 0.50 & 0.21 & 0.122 & 32.22 \\
\hline & \multicolumn{8}{|c|}{ Average } & 32.34 \\
\hline
\end{tabular}

Table.3 Silt deposited in continuous contour trenches

\begin{tabular}{|c|c|c|c|c|c|}
\hline $\begin{array}{c}\text { CCT } \\
\text { Line } \\
\text { NO. }\end{array}$ & $\begin{array}{c}\text { Length } \\
(\mathbf{m})\end{array}$ & $\begin{array}{c}\text { Average depth } \\
\text { of silt } \\
\text { deposited }(\mathbf{m})\end{array}$ & $\begin{array}{c}\text { Area of silt } \\
\text { deposition } \\
\mathbf{( m}^{\mathbf{2}} \mathbf{)}\end{array}$ & $\begin{array}{c}\text { Volume of silt } \\
\text { deposition } \\
\left(\mathbf{m}^{\mathbf{3}}\right)\end{array}$ & $\begin{array}{c}\text { Weight of silt } \\
\text { deposition } \\
\text { (tonnes) }\end{array}$ \\
\hline $\mathbf{1}$ & 180.50 & 0.16 & 90.25 & 14.44 & 18.77 \\
\hline $\mathbf{2}$ & 165.00 & 0.12 & 90.75 & 10.89 & 14.15 \\
\hline $\mathbf{3}$ & 175.00 & 0.18 & 78.75 & 14.17 & 18.42 \\
\hline $\mathbf{4}$ & 210.00 & 0.20 & 105 & 21 & 27.3 \\
\hline \multicolumn{5}{|r|}{ Total Silt deposition at Continuous Contour Trenches } \\
\hline
\end{tabular}

Table.4 design and present dimensions of earthen embankments

\begin{tabular}{|c|c|c|c|c|c|c|c|c|c|}
\hline \multirow[t]{2}{*}{$\begin{array}{l}\text { EE } \\
\text { No }\end{array}$} & \multicolumn{4}{|c|}{$\begin{array}{c}\text { Design Dimensions } \\
(2014-15)\end{array}$} & \multicolumn{4}{|c|}{$\begin{array}{c}\text { Present Dimensions } \\
(2019-20)\end{array}$} & \multirow{2}{*}{$\begin{array}{c}\text { Percent } \\
\text { reduction in } \\
\text { C/S area }\left(\mathbf{m}^{2}\right)\end{array}$} \\
\hline & $\begin{array}{l}\text { TW } \\
(\mathbf{m})\end{array}$ & $\begin{array}{l}\text { BW } \\
(\mathbf{m})\end{array}$ & $\begin{array}{c}\mathrm{D} \\
(\mathrm{m})\end{array}$ & $\begin{array}{c}\text { C/S } \\
\operatorname{Area}\left(\mathbf{m}^{2}\right)\end{array}$ & $\begin{array}{l}\text { TW } \\
(\mathbf{m})\end{array}$ & $\begin{array}{l}\text { BW } \\
(\mathbf{m})\end{array}$ & $\begin{array}{c}\mathrm{D} \\
(\mathrm{m})\end{array}$ & $\begin{array}{c}\text { C/S } \\
\operatorname{Area}\left(\mathbf{m}^{2}\right)\end{array}$ & \\
\hline 1 & 0.60 & 2.90 & 0.90 & 1.57 & 0.80 & 2.90 & 0.70 & 1.29 & 17.83 \\
\hline 2 & 0.65 & 2.75 & 1.00 & 1.70 & 0.75 & 2.75 & 0.85 & 1.48 & 12.94 \\
\hline 3 & 0.60 & 2.70 & 0.95 & 1.56 & 0.68 & 2.70 & 0.75 & 1.26 & 19.23 \\
\hline 4 & 0.65 & 2.80 & 1.10 & 1.89 & 0.78 & 2.80 & 0.90 & 1.61 & 14.81 \\
\hline \multicolumn{9}{|c|}{ Average } & 16.20 \\
\hline
\end{tabular}


Table.5 Silt deposited in earthen embankments

\begin{tabular}{|c|c|c|c|c|}
\hline $\begin{array}{l}\text { EE } \\
\text { No. }\end{array}$ & $\begin{array}{l}\text { Average depth of } \\
\text { silt deposition (m) }\end{array}$ & $\begin{array}{c}\text { Area of silt } \\
\text { deposition }\left(\mathrm{m}^{2}\right)\end{array}$ & $\begin{array}{l}\text { Volume of silt } \\
\text { deposition }\left(\mathrm{m}^{3}\right)\end{array}$ & $\begin{array}{l}\text { Weight of silt } \\
\text { deposition } \\
\text { (tonnes) }\end{array}$ \\
\hline 1 & 0.18 & 52.00 & 9.36 & 12.16 \\
\hline 2 & 0.16 & 40.00 & 6.4 & 8.32 \\
\hline 3 & 0.22 & 78.00 & 17.16 & 22.30 \\
\hline 4 & 0.17 & 48.00 & 8.16 & 10.60 \\
\hline \multicolumn{4}{|c|}{ Total Silt deposition at earthen embankments } & 53.38 \\
\hline
\end{tabular}

Table.6 The design and present dimensions of loose boulder structures

\begin{tabular}{|c|c|c|c|c|c|c|c|c|c|}
\hline $\begin{array}{c}\text { LBS } \\
\text { No }\end{array}$ & \multicolumn{4}{|c|}{ Design Dimensions } & \multicolumn{3}{c|}{ Present Dimensions } & $\begin{array}{c}\text { Percent } \\
\text { reduction in C/S } \\
\mathbf{a r e a}_{\left(\mathbf{m}^{2}\right)}\end{array}$ \\
\hline & $\begin{array}{c}\text { TW } \\
(\mathbf{m})\end{array}$ & $\begin{array}{c}\text { BW } \\
(\mathbf{m})\end{array}$ & $\begin{array}{c}\mathbf{D} \\
(\mathbf{m})\end{array}$ & $\begin{array}{c}\text { C/S } \\
\text { Area } \\
\left(\mathbf{m}^{2}\right)\end{array}$ & $\begin{array}{c}\text { TW } \\
(\mathbf{m})\end{array}$ & $\begin{array}{c}\text { BW } \\
(\mathbf{m})\end{array}$ & $\begin{array}{c}\text { D } \\
(\mathbf{m})\end{array}$ & $\begin{array}{c}\text { C/S } \\
\text { Area } \\
\left(\mathbf{m}^{2}\right)\end{array}$ & \\
\hline $\mathbf{1}$ & 0.50 & 2.10 & 1.00 & 1.300 & 0.54 & 2.10 & 0.85 & 1.122 & 13.69 \\
\hline $\mathbf{2}$ & 0.62 & 2.00 & 1.20 & 1.570 & 0.65 & 2.00 & 1.00 & 1.325 & 15.60 \\
\hline $\mathbf{3}$ & 0.50 & 2.50 & 0.90 & 1.350 & 0.55 & 2.50 & 0.70 & 1.067 & 20.96 \\
\hline $\mathbf{4}$ & 0.60 & 2.60 & 1.00 & 1.600 & 0.62 & 2.60 & 0.85 & 1.368 & 14.50 \\
\hline Average & & & & & & & & 16.18 \\
\hline
\end{tabular}

Table.7 Silt deposited at loose boulder structures

\begin{tabular}{|c|c|c|c|c|}
\hline $\begin{array}{c}\text { LBS } \\
\text { No. }\end{array}$ & $\begin{array}{c}\text { Average depth of } \\
\text { silt deposition }(\mathbf{m})\end{array}$ & $\begin{array}{c}\text { Area of silt } \\
\text { deposition } \\
\left(\mathbf{m}^{\mathbf{2}}\right)\end{array}$ & $\begin{array}{c}\text { Volume of silt } \\
\text { deposition } \\
\left.\mathbf{( m}^{\mathbf{3}}\right)\end{array}$ & $\begin{array}{c}\text { Weight of silt } \\
\text { deposition (tonnes) }\end{array}$ \\
\hline $\mathbf{1}$ & 0.28 & 38 & 10.64 & 13.83 \\
\hline $\mathbf{2}$ & 0.24 & 26 & 6.24 & 8.11 \\
\hline $\mathbf{3}$ & 0.50 & 21 & 10.5 & 13.65 \\
\hline $\mathbf{4}$ & 0.42 & 27 & 11.34 & 14.74 \\
\hline \multicolumn{2}{|l|}{ Total Silt deposition at Loose Boulder Structures } \\
\hline
\end{tabular}


Plate.1 Shows the measuring the present dimensions of continuous contour trenches located at Shevadi-Yenoli watershed 2019-20.

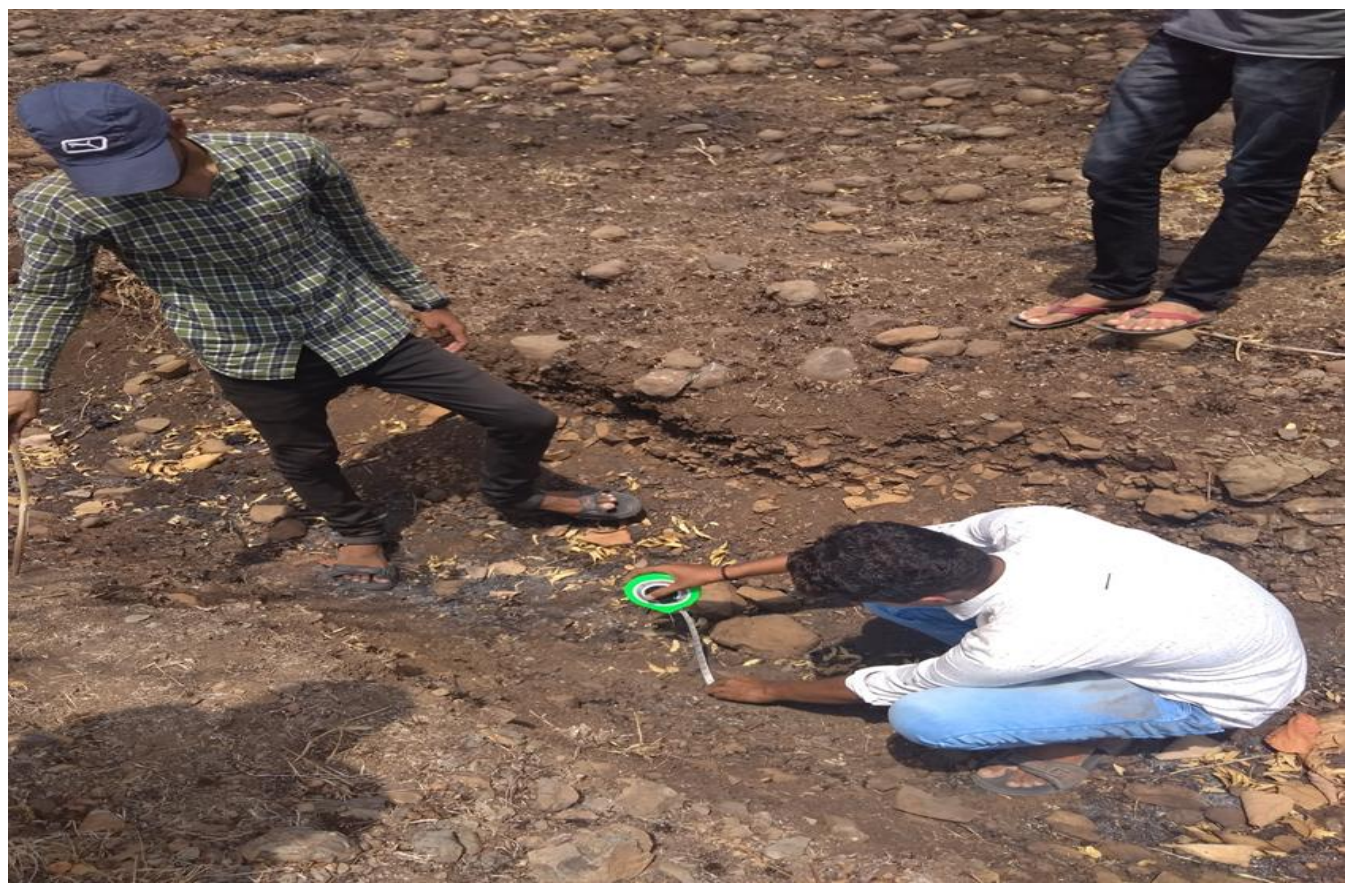

Plate.2 Measuring silt deposited in earthen embankment structures located at Shevadi- Yenoli watershed 2019-20.

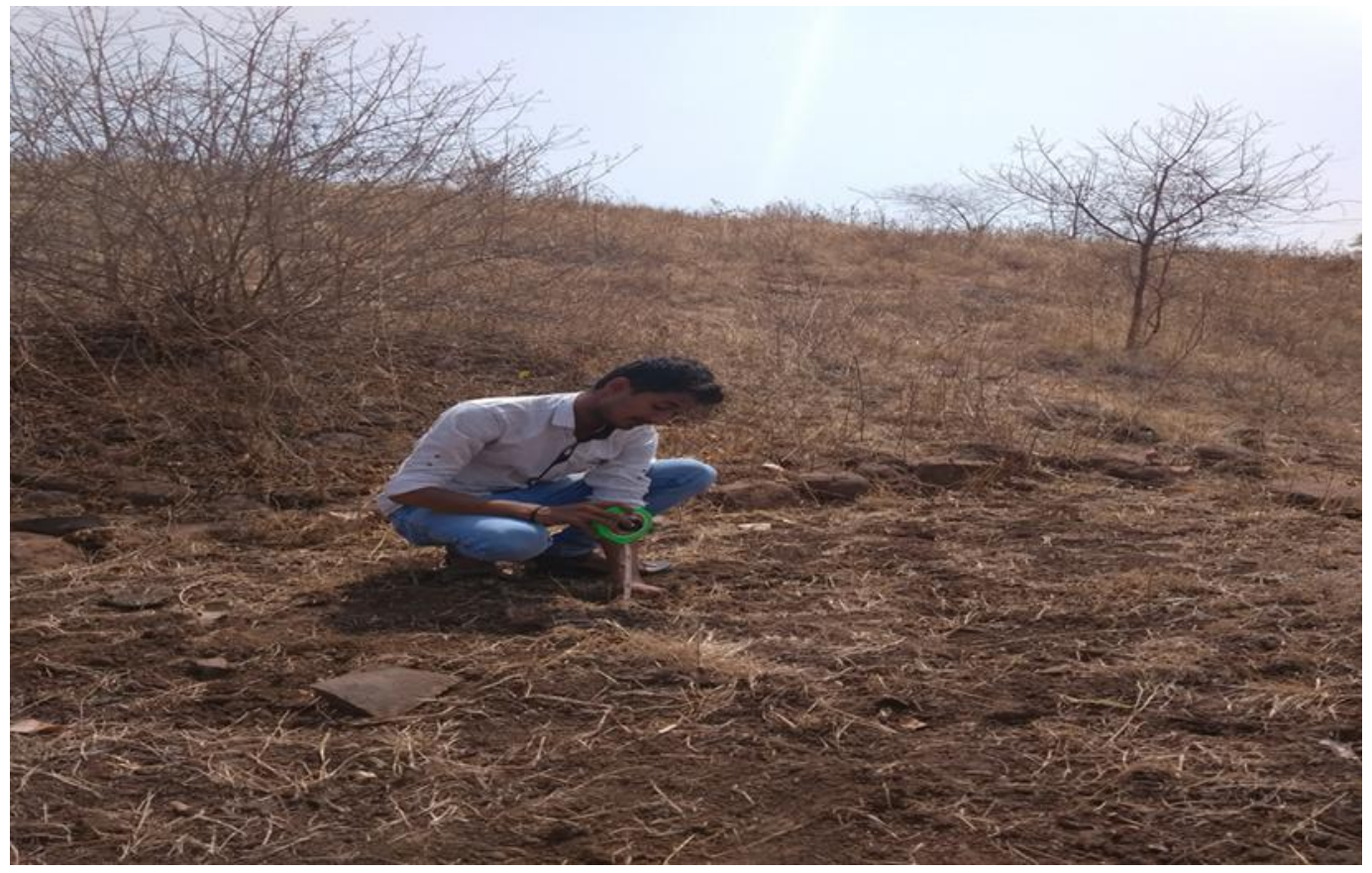


These structures also retain some quantity of sediment and moisture which helps in formation of vegetation. The raw material required for construction of loose boulder structures was simply accessible at the construction site.

\section{Changes in dimensions of loose boulder structures}

The present dimension of loose boulder structures was calculated by measuring top width, bottom width and depth with the help of measuring tape and compared with designed dimensions

It was seen from Table 6 that top width was increased and depth was reduced while bottom width remains constant the reduction in depth and increase in top width is due to the disturbance of boulders due to runoff water. The per cent reduction in cross sectional area of selected loose boulder structures was ranged between 13.69 to 20.96 per cent. On an average reduction in cross sectional area was found to be 16.18 per cent over a period of four years after their construction. It was advocated to replace the loose boulders carried with runoff water at their own place every in order to provide stability to these structures.

\section{Silt deposited in loose boulder structures}

The observations on silt deposition were calculated by depth of silt deposited in LBS ${ }^{\text {ee }}$ area. It was measured by excavating small pit to the original ground surface \& area of silt deposited was measured. Volume of silt deposited was calculated by multiplying depth and area of silt deposited. Weight of silt deposited was calculated by multiplying volume of silt deposited to bulk density of silt.

From Table 7 it was indicated that average depth of silt deposited at different loose boulder structures ranged between 0.24 to 0.50 $\mathrm{m}$ and area of silt deposition ranges between $21.00-38.00 \mathrm{~m} 2$ whereas weight of silt deposited at different loose boulder structures ranged from 8.11 to 14.74 tonnes. The total silt deposited at all four loose boulder structures was found to be 50.33 tonnes during the period of four years after construction. From the results obtained it was shown that the loose boulder structures were helped to arrest the silt flowing with water on their upstream side and also proved helpful for stabilization of the gullies. Also, they were stopped further widening and deepening of gullies. Also, deposition of silt and conservation of the moisture on upstream side of the structures created favorable condition for good vegetative cover.

The study on, 'Impact evaluation of shevadiyenoli watershed development in district Parbhani of Maharashtra' was carried out during 2019-20. Shevadi- Yenoli watershed (1772.76 ha) was developed by Department of Agriculture, Government of Maharashtra. Different soil and water conservation structures i.e., continuous contour trenches, loose boulder structures, earthen embankment were undertaken in the watershed. Representative soil and water conservation structures were selected to study the effect on reducing soil erosion and soil loss as well as increase in ground water potential of the area.

Based on the results obtained following conclusions are drawn:

It was found that the cross-sectional area of continuous contour trenches (CCT) reduced by 29.35 to 35.00 percent. The storage capacity of CCT was reduced by about 32.34 percent due to the deposition of silt.

It was found that the cross-sectional area of earthen embankment (EE) reduced by 12.94 to 19.23 percent. The storage capacity of $\mathrm{EE}$ was reduced by about 16.20 percent due to the 
deposition of silt within period of four years after construction.

It was found that the cross-sectional area of loose boulder structures (LBS) reduced by 13.69 to 20.96 percent. The storage capacity of LBS was reduced by about 16.18 percent due to the deposition of silt within period of four years after construction.

\section{Acknowledgement}

I acknowledge the, Department of Agriculture, Jintur, Government of Maharashtra, for providing necessary data and support for my research work. I would like to express my special thanks of gratitude to my advisor Prof. S.D. Payal, Assistant Professor, Department of soil and water conservation Engineering, College of Agricultural Engineering \& Technology, VNMKV Parbhani, gave me golden opportunity to do this wonderful project, which also helped me in doing a lot of research and I came to know about so many new things I am really thankful to them. Secondly, I would also like to thank my parents and friends who inspiring and support me throughout my journey.

\section{References}

Abuj M. D., Magar P.A., Bombale V.T., Bhutada S.H. and P.R. Bhandari
(2010). Impact of soil and water conservation structures on ground water recharging in Darakwadi watershed. International J. Agriculture Engineering, 3(1): 121-124.

Deshmukh, A.P. (2009). Evaluation of watershed development programme implemented in Atharwadi watershed. Unpublished M.Tech. Thesis submitted to V.N.M.K.V. Parbhani.

Dhruva Narayana (1993). Soil and water conservation research in India, book published by ICAR, New Delhi.

Ghule S.B., S.N. Pawar, S.B. Jadhav, R.T. Ramteke and B. W. Bhuibhar (2006). Performance evaluation of nala bund Karnataka J. Agril. Sci.19(1): (90-96).

Lavarale, M. S. (2003). Evaluation of soil and water conservation structures in Kachhigahati watershed. Unpublished M. tech thesis submitted to V.N.M.K.V. Parbhani.

Pendke, M.S. (2009). Qualitative evaluation of soil and water conservation structures in Daregaon watershed. Indian J. soil and water cons., vol.8, 09-13.

Rajmane, S. P. (2004). Impact study of Shamwadi watershed development programme. Unpublished M. Tech thesis submitted to V.N.M.K.V. Parbhani.

www.rkvy.nic.in.https://rkvy.nic.in/static/dow nload/compendium/Mahara shtra.pdf

\section{How to cite this article:}

Mundhe, S. C., S. D. Payal and Shewale, J. P. 2021. Qualitative Performance of Different Soil and Water Conservation Measures at Shevadi-Yenoli Watershed. Int.J.Curr.Microbiol.App.Sci. 10(02): 1605-1613. doi: https://doi.org/10.20546/ijcmas.2021.1002.191 